\title{
Sea Freight Responsibility (Transportation) in Passenger Services during the COVID-19 Pandemic
}

\author{
Edy Akhyary ${ }^{1}$, Pauzi $^{2}$, Hazriyanto $^{3}$ \\ \{edy_akhyari@umrah.ac.id ${ }^{1}$, hafifah1972@gmail.com² ${ }^{2}$ hazriyanto@gmail.com ${ }^{3}$ \}
}

Raja Ali Haji Maritime University ${ }^{1}$, STAIN Sultan Abdurrahman Kepulaun Riau ${ }^{2}$, STIE Galileo Batam ${ }^{3}$

\begin{abstract}
This scientific paper aims to investigate the responsibility of Sea Freight (Transportation) in Passenger Services during the COVID-19 Pandemic. The COVID-19 pandemic has harmed the economy of the community, especially in Indonesia in the sea freight sector. In the name of economic difficulties, many transportation services have ignored the rules made by the government and as a result, endanger passengers. Thus, the actors in the sea freight business of transportation service need to understand their responsibilities. .'
\end{abstract}

Keywords: Responsibility, Sea Freight, Passenger Services, COVID-19

\section{Introduction}

Indonesia is an archipelago in Southeast Asia consisting of 17,504 large and small islands, about 6,000 of which are uninhabited [39]. Located on the equator, the weather is tropical. Indonesia is situated between the Asian continent mainland and Oceania, at $6.1750^{\circ} \mathrm{S}$ latitude and $106.8283^{\circ} \mathrm{E}$ longitude. Between the Indian Ocean and the Pacific Ocean, Indonesia's territory extends 3,977 miles. Indonesia has a land area of $1,922,570 \mathrm{~km}^{2}$ and a water area of $3,257,483 \mathrm{~km}^{2}$. Java is Indonesia's most populated island, home to half of the country's population. Indonesia is made up of five major islands: Java, which covers 132,107 $\mathrm{km}^{2}$, Sumatra, which covers 473,606 km², Kalimantan, which covers 539,460 km², Sulawesi, which covers $189,216 \mathrm{~km}^{2}$, and Papua, which covers $421,981 \mathrm{~km}^{2}$. Indonesia's territorial boundaries are measured from the archipelago using marine territories as follows: 12 nautical miles and an exclusive economic zone of 200 nautical miles, in cardinal directions, namely North: Malaysia with a $1.782 \mathrm{~km}$ border, Singapore, the Philippines, and the South China Sea. East: the state of Papua New Guinea with a border of $820 \mathrm{~km}$, Timor Leste, and the Pacific Ocean. South: Australia, Timor Leste, and the Indonesian Ocean. West: Ocean Indonesia (No Title, n.d.).

Indonesia consists of $80 \%$ sea area and $20 \%$ land so clearly the biggest and most important transportation potential is by sea. Therefore, transportation in Indonesia has an important role in advancing and smoothing domestic and foreign trade. Transportation can facilitate the flow of goods from production areas to the passenger to meet the needs of the passenger. This can be seen in the current development of transportation services in Indonesia that are starting to show progress; an increasing number of industrial companies are using transportation services' [4]. 
Sea freight by ship is regulated by Law Number 21 of 1992 on shipping (State Gazette Number 98 of 1992). At the time of the enactment of this law, all legislation relating to water transport that had been in force since the Dutch colonial era was declared obsolete. This law came into affect two years from the date of promulgation. This law was enacted on September 17,1992 . Since it was no longer relevant to the needs that were currently developing, this law was no longer enforced and was replaced by Law Number 17 of 2008 concerning Shipping. This Shipping Law came into force on the date of promulgation, namely May 7, 2008, in State Gazette Number 64 of 2008 [23].

Furthermore, sea freight is also regulated in the Indonesian Commercial Code (Kitab Undang-undang Hukum Dagang), namely Book II Chapter V concerning Ship charter agreements; Chapter VA concerning the Transportation of Goods; and Chapter VB concerning the Transport of Passengers. The statutory regulations in the Indonesian Commercial Code are still declared to be valid. The provisions of the Indonesian Commercial Code are lex generalis. Then, based on Article 38 of Law Number 17 of 2008 concerning Shipping, transportation companies in the waters are obliged to carry passengers and/or goods, especially postal transportation as agreed in the transportation agreement. The transportation agreement in question is evidenced by passenger tickets and cargo documents. Indirectly, PT. PELNI as a company in the transportation sector is obliged to provide facilities based on the provisions stated in the ticket as proof that a sea freight agreement has occurred between the sea freight company and the passenger or owner of the goods, with payment of transportation costs [23].

Passenger tickets and water transportation documents are proof that there has been a water transportation agreement between the water transportation company and the passenger or owner of the goods, with payment of transportation costs [16]. Since the transportation document or passenger ticket is proof that an agreement has occurred and the ticket contains the rights and responsibilities of each party as long as the agreement is not against the law as regulated in Article 1365 of the Civil Code [23].

During the COVID-19 Pandemic, naturally, the law regarding transportation, especially with regards passengers, has been revised includingreducing the number of passengers (giving distance between them) and following health protocols. Unfortunately, there are many cases of sea freight services not following the regulations because of their increasingly difficult economic situation. Therefore, it is necessary for us to study Sea Freight Responsibility (Transportation) in Passenger Services during the COVID-19 Pandemic.

\section{Research Methods}

This study used a descriptive research method with a qualitative approach. A qualitative approach, according to Saifuddin Azwar, is one in which science emphasizes deductive and inductive inference methods, as well as the method of analyzing the complexities of observed phenomena using scientific logic [7]. Qualitative research conducts research in natural settings or the context of an entity. This is done because natural ontology requires the existence of facts as a whole that cannot be understood if separated from context [12]. Such an approach focuses on logically and through a phenomenological model reasoning centered on social experience, which implies that this strategy is used for three reasons, to promote the interpretation of different realities, to present intrinsically between the researcher and reality, and to be more receptive and adaptable to the value-form used [14]. A qualitative approach was used in this study based on the consideration that several realities make it easier for 
researchers to carry out their studies. Moreover, this approach can help sharpening of influence and value patterns to be more sensitive to adjust.

\section{Results And Discussion}

\subsection{The Concept of Responsibility}

The definition of responsibility according to the Great Dictionary of the Indonesian Language is, 'the condition of being obliged to bear everything (if anything happens, they can be prosecuted, blamed, sued, et cetera) (Digital KBBI). Responsibility is human awareness of behavior or actions that are intentional or unintentional. Responsibility also means acting as a manifestation of the awareness of one's obligation. Responsibility is natural, meaning that it has become a part of human life, that every human being must be burdened with responsibility. If he does not want to be responsible, then other parties impose that responsibility. Thus, the responsibility can be seen from two sides, namely from the side of the party who did it and from the side of the interests of the other party. Responsibility is characteristic of civilized humans (cultured). Humans feel responsible because they are aware of the good or bad consequences of their actions, and also realize that other parties need their dedication or sacrifice. To gain or increase responsible awareness, efforts need to be made through education, counseling, exemplary, and piety to God Almighty.'

Responsibility can be divided into three parts, namely vertical, a responsibility to God; horizontal, a responsibility that correlates with other things outside of oneself and personal, a responsibility that concerns the substance of itself. The part can be described as follows [16].

1. Responsibility to Allah SWT.

a. Responsibility to Allah is the highest responsibility of human existence because the main purpose of religion is to serve God. Humans who have a strong value of responsibility to God will have a positive effect on other forms of responsibility (to creatures). As for the form of human responsibility to God, among them are:

b. Devoting oneself to Allah SWT as the essence of a servant by worshiping, doing good deeds

c. Sticking to the religion of Allah SWT.

d. Holding the trust to be the Caliph fil Ardhi.

e. Maintaining the purity of religion, by upholding Islam by preaching both personally and individually.

f. Protecting yourself and your family from the hellfire.

g. Educating children and families with religious education.

2. Responsibility to Yourself

Responsibility to oneself is a personal responsibility that requires motivation from within yourself. This personal responsibility is sometimes too heavy if there is no continuous training. There are many people or other things because of the impulse of shame or compulsion. However, personal responsibility depends on the human being itself.

Responsibility to oneself determines the awareness of each person to fulfill their obligations in developing the personality as a person. Thus, it can solve humanity's problems regarding itself according to the nature of human is a moral being, but a human is also a person. Because human is a person, human has his own opinion, feelings, and 
dreams. As a manifestation of opinions, feelings, and dreams, humans act. In this case, humans are not free from mistakes, whether intentional or not.

The forms of responsibility to oneself are:

a. Cleaning yourself both physically and spiritually.

b. Being independent in doing daily chores Following the rules that have been made by oneself, for example, students who make daily work and study schedules, then he must be responsible for what he has made for himself.

3. Responsibility to Duty (Amanah)

A duty is a mandate that must be done or that is determined to be done or a job that is the responsibility of a person or can also be interpreted as an order that must be carried out properly and correctly. Each of us has our respective duties according to our level in social life. Fathers, mothers, children, school principals, directors, officials, and so on have responsibilities for their duties. A father has the responsibility to provide for the needs of his children and wife. The wife is responsible for safeguarding property, children, and their families. The principal has responsibility to the staff and students. All must run according to the rules. If someone leaves their responsibilities in carrying out duties, there will be chaos in life or in the language of religion, which is not a mandate.

4. Responsibilities to the Family

In the Great Dictionary of the Indonesian Language, the word "family" means "mother and father and their children; the whole house" (Digital KBBI). "The family is the smallest and most important social unit for a child before they are acquainted with the world around him. He will first become acquainted with the family situation. The experience of socializing in the family will have a very big influence on the development of children in the future. It is the family that will give the color of a child's life, both behavior, character, and daily habits. The family is the place where a child gets forged for the first time which then determines the good and bad of life afterward in society. Therefore, it is no longer wrong if the family is an important element in determining the good and bad of society' [2].

According to the DKI Jakarta Disputes and Divorce Marriage Advisory Board, the family is the smallest community consisting of at least a husband or wife partner as well as the children born to them. The smallest unit in society, which consists of more than two people living together because of marriage or blood ties, consists of the father, mother, and child [1]. According to the sociological viewpoint, the family in a broad sense includes all parties who are related by blood and/or descent, while in the narrow sense family includes partners and their children [21]. According to Ramayulis, the family is the first unit and the first institution in a society where the relationships contained in it are most direct. That is where the individual develops and that is where the early stages of development are formed and interaction with them begins, he acquires knowledge, skills, interests, and attitudes in life [22].

According to Ibrahim Amini, families are people who continuously or often live with the child, such as father, mother, grandfather, grandmother, brothers, sisters, and domestic servants, among them because they have the responsibility to look after and nurturing the child and that causes the child to be born into the world, has a very important role and a greater obligation to the child's education. Being a father and mother is not only to give birth to a child. Both parents are said to have the qualifications to be a father and mother while they are diligent in educating their children. Islam considers education as one of the rights of children, which if both parents neglect it means that they have wronged their children, and later on the Day of Judgment, they will be held accountable. Rasulullah SAW said: 'All of you are 
leaders, and every leader will be held accountable for the people he leads." A ruler is a leader and person in charge of his people. A man is a leader and person in charge of his family. Moreover, a woman is a leader and person in charge of her household, husband, and children [3].

The examples of family responsibilities are:

a. Father is responsible for providing a sense of security to all family members (children and wife) both in primary and secondary needs.

b. Mother is responsible for educating, looking after, caring for their assets and children both physically and spiritually.

c. Children have the responsibility to obey and serve their parents and protect the good name of their family.

\section{Responsibility to the Community}

Humans are social creatures who cannot live without the help of other humans, according to their position as members of society. Since human needs other humans, they must communicate with other humans. Thus, humans as members of society certainly have responsibilities like other members of society. Naturally, all of his behavior and deeds must be accountable to the community, such as the Islamic community.

'Islamic society is defined as a group of people living netted by Islamic culture, which is practiced by the group as its culture as the group works together and lives based on the principles of the Qur'an and Sunnah in every aspect of life' [11]. Islamic society is also defined as a universal society, that is, non-racial, non-national, and not limited to geographic boundaries. He is open to all human children regardless of type, skin color, or language, even regardless of religion and belief/aqidah [20].

Society in the view of Islam is a tool or means to carry out Islamic teachings concerning life together. For this reason, society must become the basis for the framework of worldly life for the unity and cooperation of the people towards the existence of a human growth that embodies equality and justice. Community development is required to start with each individual being obliged to take care of himself and improve the quality of life. Therefore, in life, human is obliged to take care of himself, improve the quality of life, to be useful for society in living in that society and is also not detrimental between other. Islam teaches that the quality of humans can be seen from one point of view from the benefits for other humans. This view of the status and function of the individual, Islam provides a complete moral code. This complete moral code is based on the timing of a value system that contains the same norms as the rays of religious demands such as devotion, surrender, truth, justice, compassion, wisdom, beauty, and so on [11].

Fazlur Rahman as quoted by Ahmad Syafi'i Ma'arif stated that the main purpose of the Qur'an is to create a stable and living social order on earth, which is fair and based on ethics. In the Islamic perspective, whether the individual is more important or society, is not a question of truth, which is clear between individuals and society must be interdependent and interconnected. For example, one will not know individuals without society, which Islam emphasizes is the need for ontological peace for the construction of a society and a civilization in which transcendental moral principles are its primary foundation [13].

A group of people whose life in human relations is based on Islamic culture is what is called Islamic society, but a group of people whose life only in the relationship between humans and God is based on Islam, according to a scientific viewpoint, cannot be termed an Islamic society, but rather a society Islam [9]. Therefore, people who live in an Islamic society 
are responsible for keeping things that are not in accordance with Islamic rules, or in other words, they must be accountable for their behavior in Islamic community life.

\subsection{Concept of Transportation}

The word 'transport' means to lift and carry (Digital KBBI). In the legal dictionary, it is stated that transportation is a reciprocal agreement between the carrier and the sender, in which the carrier binds himself to carry out the transportation of goods and/or people from one place to a certain destination safely, while the sender binds himself to pay the transportation money [24]. including:

There are several opinions regarding the meaning of transportation from scholars,

1. According to Lestari Ningrum, transportation is a series of activities (events) of moving passengers and/or goods from one place of loading (embargo) to their destination as a place to drop passengers or unload cargo. The series of moving events include activities are as follows: (a) In a broad sense, namely Loading passengers and/or foods into the transportation means, Carrying passengers and/or goods to their destination, Unloading passengers or unloading goods at their destination; (b) In a narrow sense, namely the activity of carrying passengers and/or goods from the station/terminal/port/airport of departure to the station/terminal/port/airport of destination [17].

2. According to Abdulkadir Muhammad, transportation is the process of carrying goods or passengers from the loading point to the destination and unloading the goods or passengers from the vehicle to the specified place [15].

In transportation, there are several scopes or classifications in the operation of transportation which also determines the supporting aspects as well as the laws and regulations that can be carried out in the transportation. The classification is as follows:

1. Land Transportation. Inland transportation, in order to achieve the expected results and its transportation functions to be achieved, transportation requires several elements that are adequate in the form of:

a. The means of transportation (operating facilities). Every item or person to be transported requires adequate means of transportation, both in capacity, size, and equipment. The means of transportation in question can be in the form of trucks, trains, ships, buses, or aircraft. The equipment provided must match the goods being transported.

b. Facilities that will be passed by means of transportation (right of way). These facilities can be in the form of public roads, railways, waters/rivers, navigation airports, and so on. Therefore, if the facilities through which the transportation passes are not available or are not available perfectly, the transportation process itself may not run well.

c. Terminal facilities. Terminal facilities are required because a transport activity cannot run effectively if there is no terminal used as a preparation place before and after the transport process begins.

d. Moreover, in the world of transportation trade plays a very important role. Not only as a means of transportation that must carry traded goods to passengers but also as a means of determining the price of these goods. Therefore, to expedite its business, producers will look for sustainable transportation and cheap transportation costs [10].

2. Air Transport. Air transport in the Air Transport Ordonnantie uses the term carrier as one of the parties entering into a transport agreement. Carriers on air transport are Air 
Transport Companies that obtain operating licenses from the government using civilian aircraft by charging a fee [15].

3. Sea freight. Sea freight has norms that regulate human behavior in carrying out its duties to prepare, carry out and launch a voyage at sea. Thus, the law of sea freight is also called the Law of shipping. Furthermore, Prof. Soekardono divides the Law of the Sea into 2 (two), namely the Civil Law of the Sea and the Law of the Public Ocean. The law of the sea is civil or private because the law of the sea regulates the relationship between individuals. In other words, people are legal subjects. Based on Article 6 of Law No. 17 of 2008 concerning Shipping, transportation in waters consists of sea, river, lake, and crossing transportation [23]. as follows:

a. Sea freight. Sea freight is a transportation activity that, according to its activities, serves sea transportation activities.

b. River and Lake Transportation. Ferry transportation is a term that consists of two aspects, namely river and lake transportation. The term river and lake transportation refer to a type of mode of transportation or type of transportation in which a transportation system consists of 5 types, namely land transportation modes (roads), air transportation modes, rail transportation modes, pipeline transportation models (which may not be widely known), sea transportation modes, and river and lake and crossing transportation modes. Inland water transportation or is another term for river and lake transportation. This type of transportation has long been known by humans and is even considered traditional. Before using road transportation by riding animals such as horses and cows, humans have used rivers to travel long distances. Likewise in Indonesia, rivers are a favorite area that causes many centers of settlement, economy, culture, and big cities on the banks of rivers such as Palembang. Inland water transportation is a term that is absorbed from English, namely Inland Waterways or also in French, namely Navigation d'Interieure or so-called voies navigable which has the same meaning, shipping or transportation activities that take place in waters that are inland areas such as rivers, lakes, and canals. Meanwhile, according to Government Regulation No. 20 of 2010 concerning transportation in water, especially article 1, inland water transportation, also known as river and lake transportation, is described as transportation via rivers, swamps, flood canals, and canals. Inland water transportation is part of Indonesia's national transportation system's land transportation sub-system. This mode of transportation certainly does not use marine waters as its main infrastructure, but inland waters. In the dictionary of the Association of Transportation Terms, the term inland waters are defined as all lake waters, canals, and rivers from upstream to the estuary as stated in the laws or regulations regarding inland water areas.

c. Crossing Transportation. Crossing transportation is transportation that functions as a moveable bridge that connects road networks and/or rail networks that are cut off due to water. In English, this mode is known as ferry transport. The Merak - Bakauheni, and Palembang - Bangka crossings are some of the well-known examples. Apart from those mentioned above, there are still types of sea freight based on Article 7 of Law No. 17 of 2008 concerning Shipping, Domestic Sea freight, Foreign Sea freight, Special Sea freight, and People's Shipping Sea Transportation.

d. Domestic Sea freight is sea transportation actively carried out in Indonesian territorial waters which is carried out by a national sea transportation company or in the sense that it is carried out by using the boundaries of domestic sovereignty [23].

Sea freight can be done by ship, whose arrangements are in: 
4. Commercial Code, in Book II Chapter V on Ship Charter Agreements, Book II Chapter VA on the Transportation of Goods, and Book II Chapter VB on the Transportation of Persons. Legislative regulations, namely Law Number 17 of 2008 concerning Shipping (in lieu of Law Number 21 of 1992 concerning shipping) [23].

\section{Conclusion}

Transportation in Indonesia has an important role in advancing domestic and foreign trade because transportation can facilitate the flow of goods from production areas to consumers to meet the needs of the consumer. This can be seen in the current development of transportation services in Indonesia which is starting to show progress, as evidenced by the sign of many industrial companies that believe in using transportation services. According to Purwosutjipto, transportation is a reciprocal agreement between the carrier and the sender, where the carrier binds himself to carry out the transportation of goods and/or people from a certain place to a certain destination safely, while the sender binds himself to pay the transportation money [19].

The purpose of transportation is to move goods from the place of origin to the destination to achieve and increase benefits and efficiency. Broadly speaking modes of transport can be classified as follows: land transport (transport by road (highway) and rail), marine transport, and air transport. Of the three modes of transport mentioned above, transport by sea has a very big role in transport for Indonesia. Sea freight is the most widely used because it can provide the following advantages: (1) Transportation costs are cheaper than other means of transportation. (2) Transportation is able to carry passengers as well as transport goods weighing hundreds or even thousands of tons [4].

The transportation of humans or passengers during the COVID-19 pandemic must follow health protocols and government regulations regarding cargo from sea freight. However, the current difficult economic situation has led some sea freight actors to continue their usual transportation service activities, prior to the COVID-19 pandemic. Consequently, sea travel is very dangerous for passengers. This has to do with responsibility to the community.

As the author mentioned above, humans are social creatures who cannot live without the help of other humans, according to their position as members of society. Because he needs other humans, he must communicate with other humans. Thus, humans as members of society certainly have responsibilities like other members of society. Therefore, they can carry out their lives in that society. Naturally, all his behavior and actions should be held accountable to society. However, the responsibility of this society only materializes when the responsibility to God has been fulfilled in one's actions. Therefore, in any case, the spiritual dimension (heart/feelings) comes first compared to intellect and lust. Thus, even in this COVID-19 pandemic, the economic activity of the community is very heavy, but if it endangers the lives of other human beings, then it still follows as mandated by the government regarding the rules in marine transport.

Responsibility to God means that we do what we should do as humans according to His commands and stay away from His prohibitions. We have a responsibility to God Almighty to worship according to our respective religions and beliefs. Many things are actually our responsibility, such as making good deeds, because the responsibility we carry is not only in this world but also in the hereafter. Everything we do in the world is judged by God Almighty. 
That is why in acting it is better to pay attention to the aspect of the Supreme Lordship (Brainly, n.d.).

\section{Acknowledgment}

The author would like to thank UMRAH, STAIN, STIE Galileo, and partner lecturers.

\section{References}

[1] Ahmadi, A. (1991). Basic Social Sciences. PT. Renika Cipta.

[2] Al-Abrasy, A. (1993). Basics of Islamic Education. Bulan Bintang.

[3] Amini, I. (2006). In Order Not To Educate Children Wrong. Al-Huda.

[4] Anantyo, S., et al. (2012). Diponegoro Law Review Volume 1 Number 4 of 2012 (Transportation by Sea). Diponegoro Law Review.

[5] Anantyo, S., Susetyo, H., \& Budiharto. (2012). Responsibility of the Carrier for Cargo in Transportation by Sea. DIPONEGORO LAW REVIEW, 1(4), 1-6.

[6] Anwar, S. S. (2014). Educational Responsibility in the Perspective of Religious Psychology. PSYMPATHIC, 7(Scientific Journal of Psychology), 1-114.

[7] Azwar, S. (2005). Research Method. Pustaka Pelajar.

[8] Brainly. (n.d.). No Title. https://brainly.co.id/tugas/32600525\#: :text=Tanggung jawab kepada tuhan berarti,perintahNya dan menjauhi larangan-laranganNya.\&text=Segala sesuatu yang kita lakukan,oleh Tuhan Yang Maha Esa.

[9] Gazalba, S. (1976). Islamic Society Introduction to Sociology and Sociography. Bulan Bintang.

[10] Hartono, S. R. (1980). Freight and Land Transportation Law. Diponegoro University.

[11] HD, K. (1992). Islam and Social Aspects. Bumi Aksara.

[12] Lincoln, Y. S., \& Guba, E. G. (1985). Naturalistic Inquiry. Sage Publications.

[13] Maarif, A. S. (1995). Ground Islam. Pustaka Pelajar.

[14] Moeloeng, L. J. (2000). Qualitative Research Methodology. PT. Remaja Rosdakarya.

[15] Muhammad, A. (1991). Land, Sea, Air Freight Law. PT. Citra Aditya Bakti.

[16] Muhammad, A. (2013). Commercial Transportation Law. PT. Citra Bakti.

[17] Ningrum, L. (2004). Travel and Tourism Business in a Business Law Perspective. PT. Citra Aditya Bakti.

[18] No Title. (n.d.). https://id.wikipedia.org/wiki/Indonesia\#Geografi

[19] Purwosutjipto. (1991). Basic Understanding of Indonesian Commercial Law 3, Transportation Law. Djambatan.

[20] Qutb, S. (1987). Islamic Society. Al-Ma'arif.

[21] Rahmat, J. (1994). Muslim Families in Modern Society. PT. Remaja Rosdakarya.

[22] Ramayulis. (1987). Islamic Education in Household. Kalam Mulia.

[23] Suyudi, A. (2017). Responsibility for Sea Freight Services by PT. Pelni on Passengers. Hasanuddin University.

[24] Widagdo, S. (2012). Legal Dictionary. PT. Prestasi Pustaka. 